$1-1-1962$

\title{
A nomograph for determining poultry house ventilation and insulation requirements
}

Jerry O. Newman

\author{
A. D. Longhouse
}

Follow this and additional works at: https://researchrepository.wvu.edu/ wv_agricultural_and_forestry_experiment_station_bulletins

\section{Digital Commons Citation}

Newman, Jerry O. and Longhouse, A. D., "A nomograph for determining poultry house ventilation and insulation requirements" (1962). West Virginia Agricultural and Forestry Experiment Station Bulletins. 468T.

https://researchrepository.wvu.edu/wv_agricultural_and_forestry_experiment_station_bulletins/650 @ WVU. It has been accepted for inclusion in West Virginia Agricultural and Forestry Experiment Station Bulletins by an authorized administrator of The Research Repository @ WVU. For more information, please contact ian.harmon@mail.wvu.edu. 

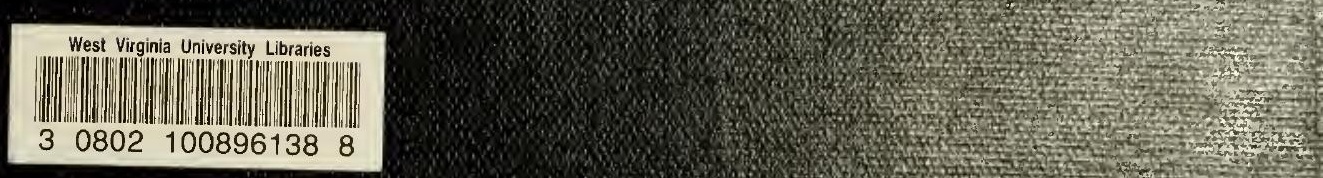

\section{.}




\section{Digitized by the Internet Archive in 2010 with funding from \\ Lyrasis Members and Sloan Foundation}




\section{A NOMOGRAPH}

For Determining Poultry House Ventilation

And Insulation Requirements

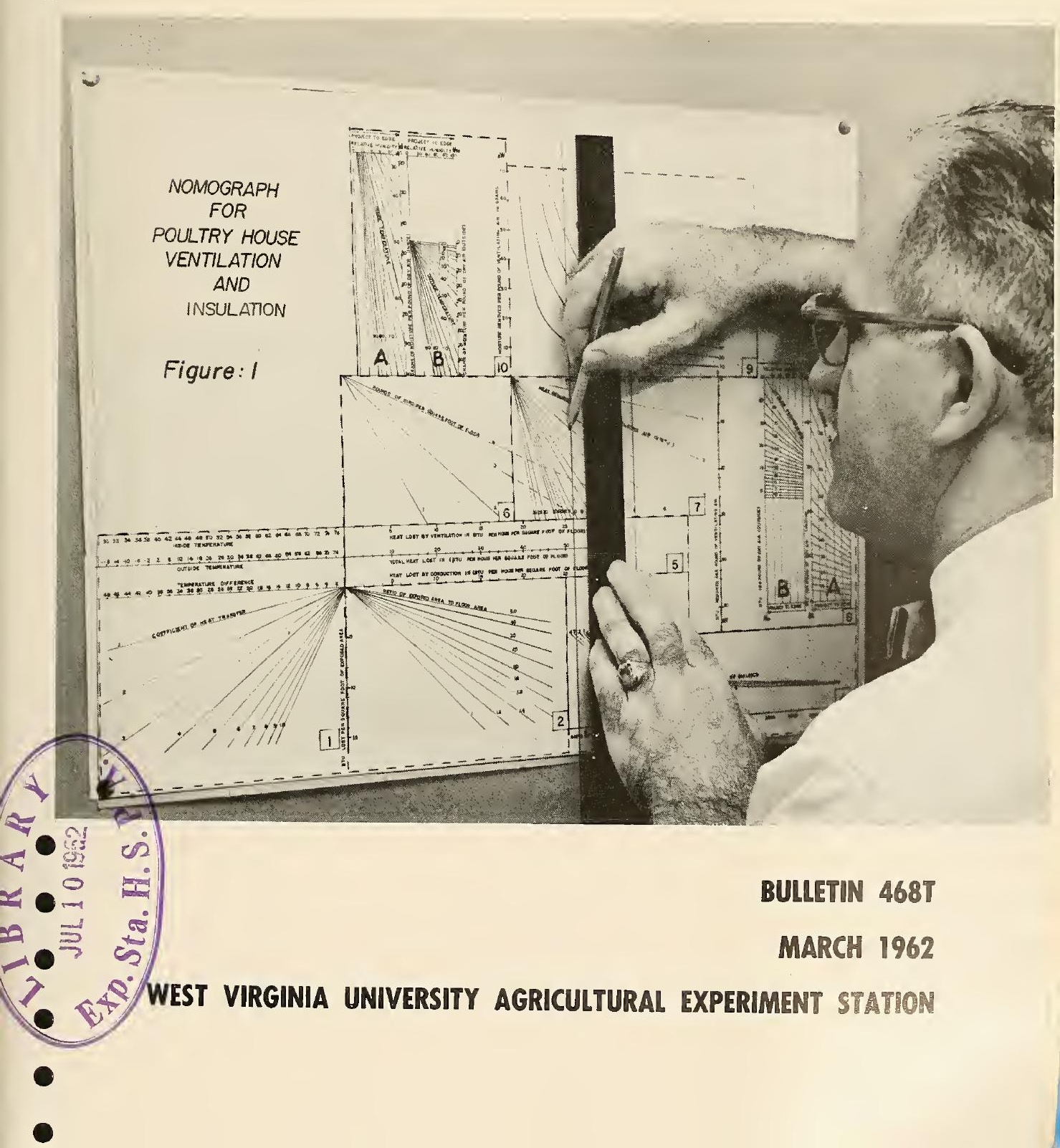




\title{
Summary
}

This bulletin provides a means for determining ventilation and insulation requirements for poultry without the necessity of computing this information for each house. The nomograph presented herein is equally useful for determining ventilation needs in an existing poultry house or for determining insulation requirements for a house to be constructed.

The nomograph is extremely flexible for many shapes and sizes of poultry houses. Simple equations have been provided to supplement limitations that occur. Only the basic data-wet and dry bulb temperature, bird density, house size, house insulation, and heat and moisture production-are needed to make insulation and ventilation determinations.

Several types of problems can be solved with the nomograph. Plates 1 and 2 are used to solve conduction heat transfer problems $(Q=U A \triangle T)$. Plates 6,8 , and 9 handle ventilation problems based on both heat conservation and moisture removal. Plate 5 is used to determine total heat loss by conduction or ventilation loss. Plates 3 and 4 are used to determine the ratio of exposed area to floor area. Plate 10 is used to determine the moisture removed per pound of ventilating air, and Plate 8 is used to determine the heat removed by each pound of ventilating air.

\section{THE AUTHORS}

Authors of A Nomograph for Determining Poultry House Ventilation and Insulation Requirements are Jerry Newman, formerly Graduate Assistant in the Department of Agricultural Engineering, and A. D. Longhouse, Agricultural Engineer.

The development of this nomograph was supported in part by funds from the North East Regional Research Project NE-8, "Essentials of Poultry Housing in the North East." NE-8 is a cooperative study involving agricultural experiment stations in twelve northeastern States.

\author{
West Virginia UnIVERSity \\ Agricultural Experiment Station \\ College of Agriculture, Fonestry, and Home Economics \\ A. H. Vanlandingham, Director \\ MORGantown
}




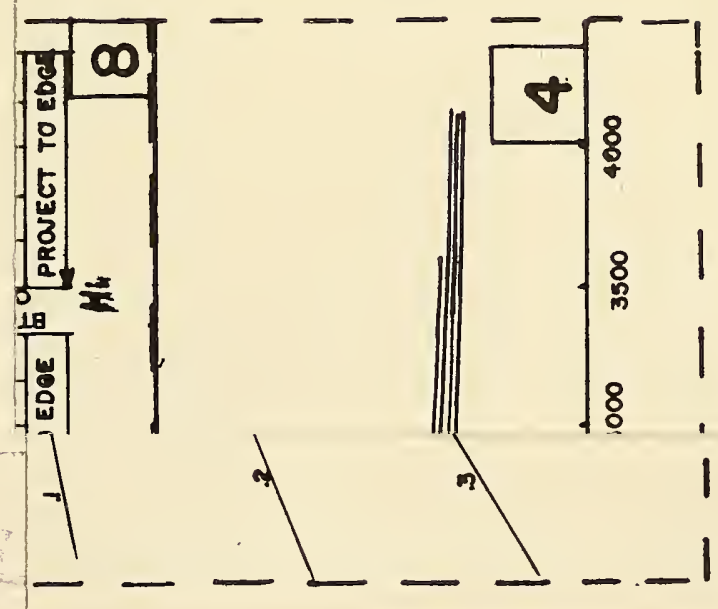




\section{NOMOGRAPH FOR \\ POULTRY HOUSE VENTILATION AND INSULATION}

SUPPLEMENT

WEST VIRGINIA UNIVERSITY AGRICULTURAL EXPERIMENT STATION

BULLETIN 468T MARCH 1962

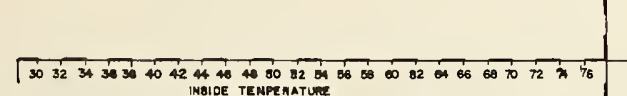

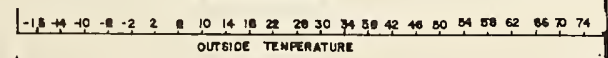
1 TEMPERATUäe OIFF ERENCE

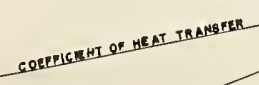
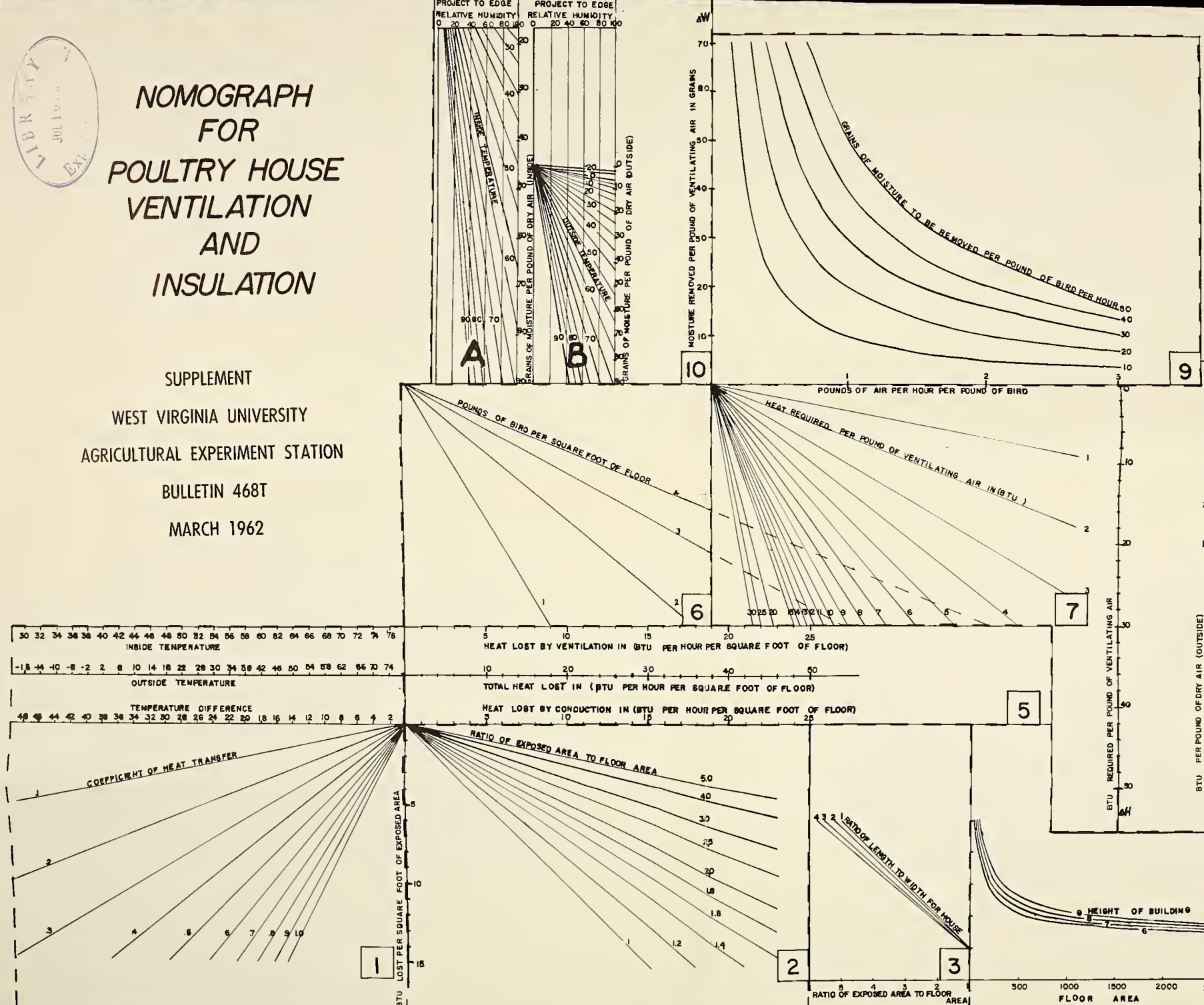

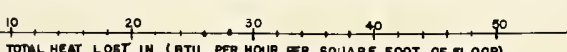
LOLET LOET IN (PTU PER HOUR FER BQUARE FOOT OF FLOOR)

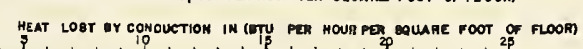
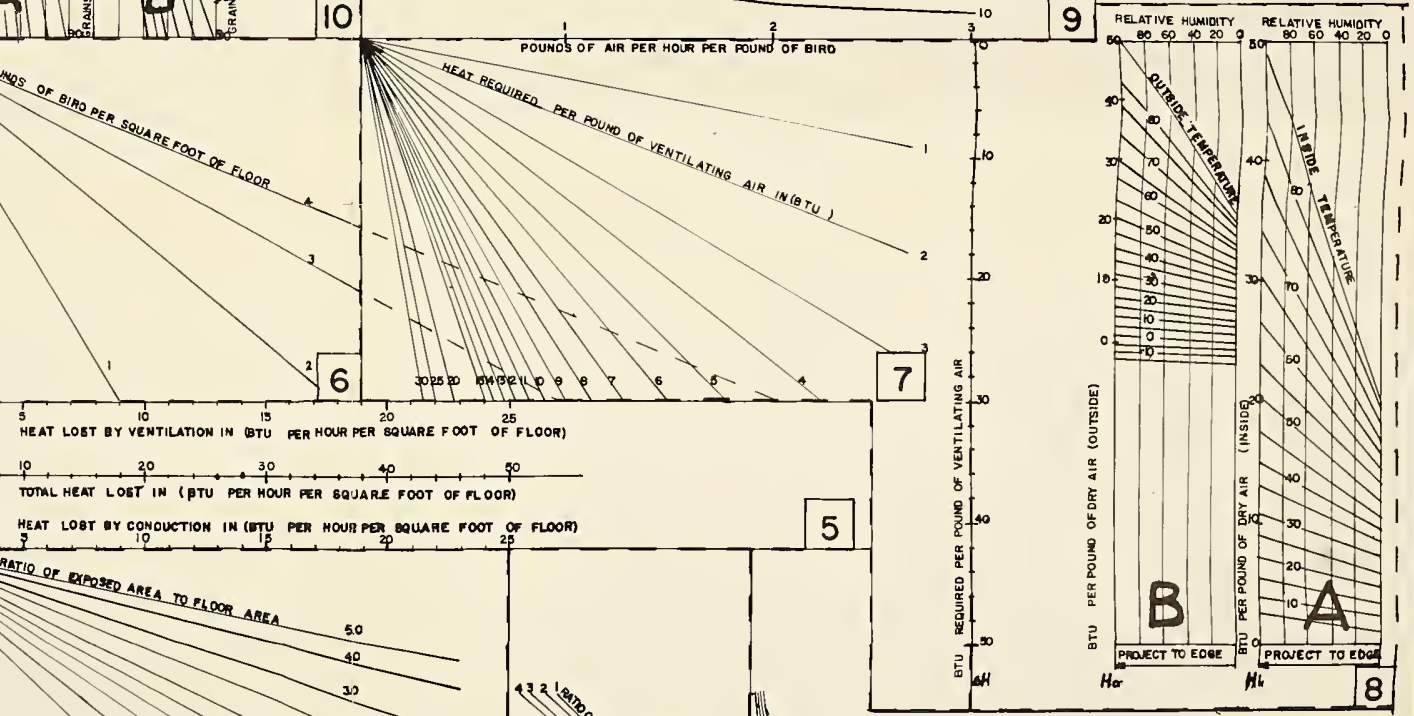
屈

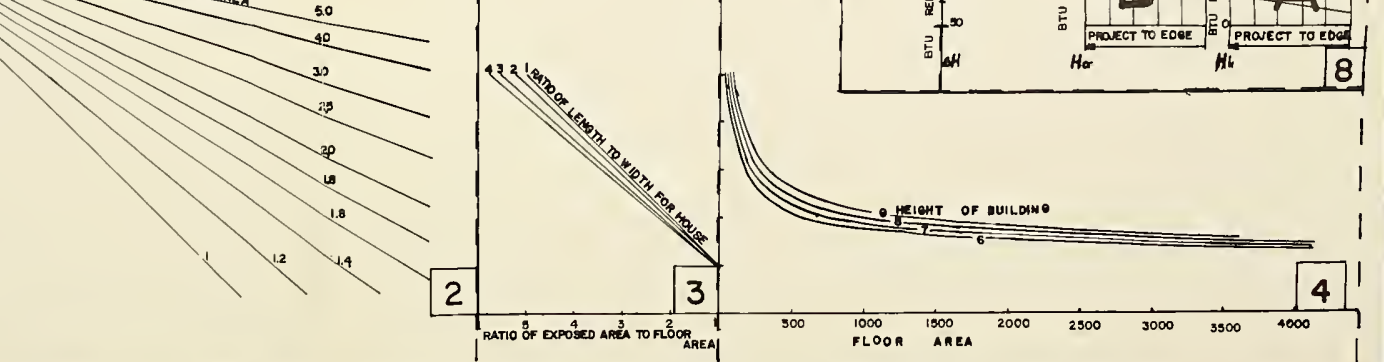




\section{A NOMOGRAPH}

\section{For Determining Poultry House Ventilation}

\section{And Insulation Requirements}

JERRY NEWMAN and A. D. LONGHOUSE

\section{Introduction}

THE purpose of this bulletin is to provide a means for determining ventilation and insulation requirements for poultry without having to do tedious mathematical calculations for each house. The nomograph presented herein is equally usefuI for determining ventilation needs for poultry in an existing house or for determining insulation requirements for a house to be constructed.

A poultry-house insulation and ventilation guide must allow all physical elements to be variable, so as to permit its use for any set of conditions. The conditions for which this nomograph were developed are broad and flexible, and thus meet this requirement.

The system has been divided into ten plates to provide for easier explanation and to permit the individual plates to be enlarged for more accurate use. Figure 1 is a composite of the ten plates.

The system for poultry house ventilation, Figure 1 , permits one to determine the quantity of air required to adequately ventilate the house and the quantity of heat required to replace that lost from the house. The basic atmospheric and physical elements of a poultry house (inside and outside temperatures and relative humidity, moisture produced, bird density, size and shape of house, and average insulation) can be varied to fit any combination of environmental conditions. If necessary, scales of individual sections of the nomograph can be extended to fit any combination of data.*

\section{Developing the System}

Four types of nomographs were used in developing this nomograph system. These were the addition nomograph, the subtraction nomograph, the multiplication nomograph, and the division nomograph.

*Figure 1, enlarged to approximately $17 \times 22$ inches, "is enclosed with this bulletin.
Plate 5, the addition nomograph, consists of three parallel scales equally spaced. The center scale is the total scale, and the outer scale shows the numbers to be added. The interval between succeeding numbers on the center scale is one-half that of the outer scales, and the three scales are positive in the same direction. A straight line intersecting all of the scales indicates a solution to the equation $\mathrm{X}+\mathrm{Y}=\mathrm{Z}$.

Plate 8 , the substraction nomograph, also consists of three parallel scales. The minuend scale is on the right, the subtrahend scale is in the center, and the difference scale is on the left. The minuend 'and subtrahend scales are positive in the same direction, but the difference scale is positive in the opposite direction. The minuend and difference scales each have the same interval between succeeding numbers, but the subtrahend scale (center) has only one half the interval between succeeding numbers as the other scales. The scales are arranged so that a straight line intersecting them indicates the solution to the equation $\mathrm{X}-\mathrm{Y}=\mathrm{Z}$.

Plate 6, the multiplication nomograph, consists of a horizontal axis and a vertical axis, together with a family of curves within them. These curves, one for each multiplier, are arranged so that by projecting the multiplicand to the multiplier curve, pivoting, and moving to the product scale, one finds the solution to the equation $\mathrm{XY}=\mathrm{Z}$.

Plate 9, the division nomograph, also consists of horizontal and vertical axes with a family of curves within. One axis serves as the divisor, the other as the quotient scale, and each of the curves represents a particular dividend. The curves are arranged so that if one projects the divisor to the dividend curve, pivots, and then moves to the quotient scale, he will obtain the solution to the equation $\mathrm{X} / \mathrm{Y}=\mathrm{Z}$. 


\section{Description of Nomographs}

\section{PLATE 1}

Plate 1 combines a subtraction nomograph and a multiplication nomograph. The subtraction nomograph, the upper one, is used to determine the difference between inside and outside temperatures. The lower nomograph, for multiplication, is used to multiply the temperature difference by the coefficient of heat transfer to determine the heat loss per square foot of exposed area per hour. In this case: *

$\mathrm{Q} / \mathrm{A}=\mathrm{U} \Delta \mathrm{T}$

$\mathrm{Q} / \mathrm{A}=$ heat loss per square foot of exposed area (Btuh)

$\mathrm{U}=$ coefficient of heat transfer, Btu $/ \mathrm{Hr} / \mathrm{ft}^{2} /{ }^{\circ} \mathrm{F}$.

$\Delta \mathrm{T}=$ temperature difference, ${ }^{\circ} \mathrm{F}$.

**A list of symbols and nomenclature used in this publication may be found on page 16 .

\section{PLATE 2}

Plate 2 is a multiplication nomograph used to convert the heat loss per square foot of exposed area per hour to heat loss per square foot of floor per hour. This heat loss per square foot of exposed area per hour is multiplied by the ratio of exposed area to floor area.

\section{PLATES 3 AND 4}

Plates 3 and 4 were developed from the equation:

$$
\begin{aligned}
\mathrm{E} & =(\mathrm{bl}+2 \mathrm{hl}+2 \mathrm{bh}) / \mathrm{bl} \\
& =1+2 \mathrm{~h} / \mathrm{b}+2 \mathrm{~h} / 1 \\
& =1+2 \mathrm{~h} / \mathrm{b}+2 \mathrm{~h} / \mathrm{rb} \\
& =\text { Ratio of exposed area to floor area }
\end{aligned}
$$

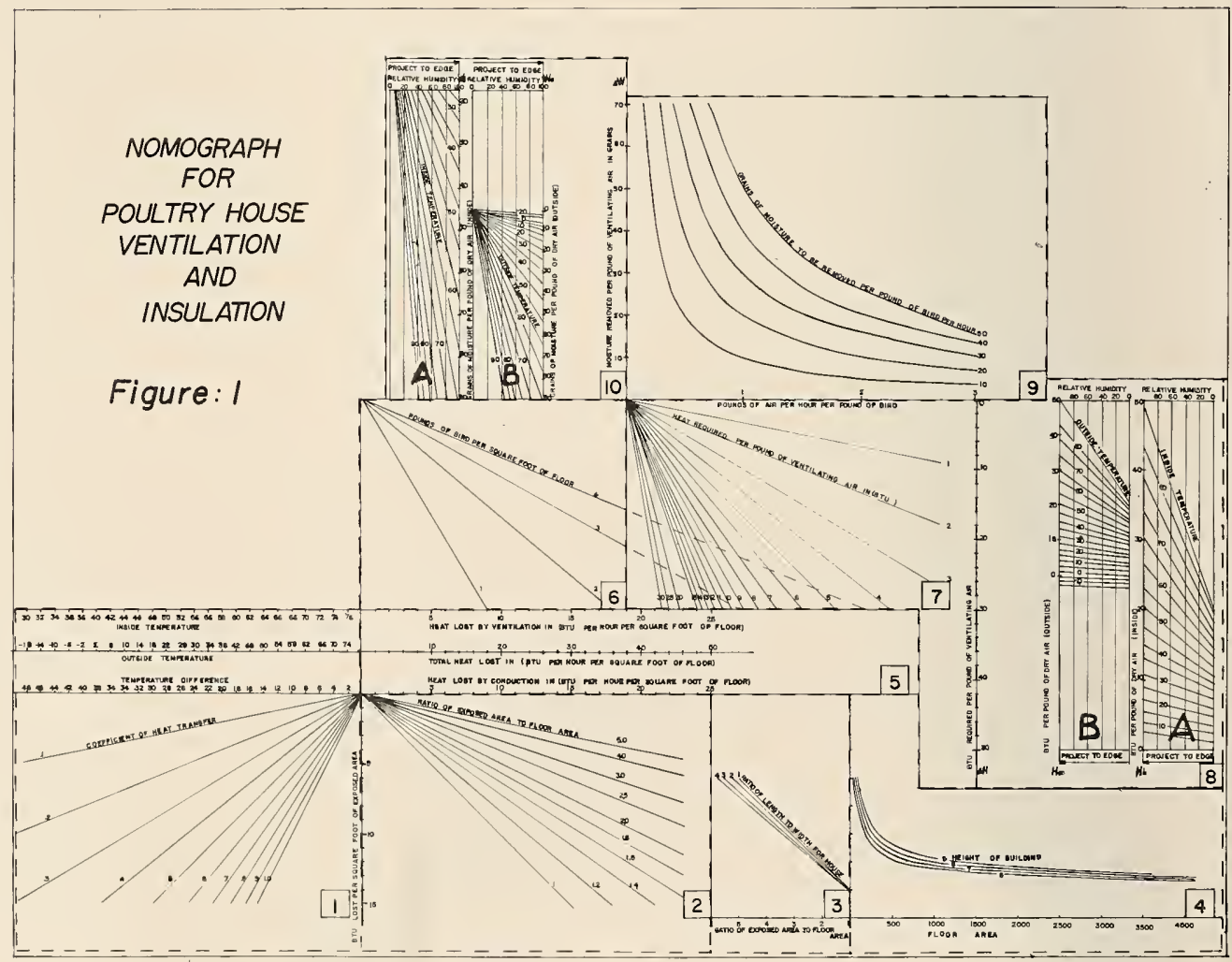


INSIDE TEMPERATURE

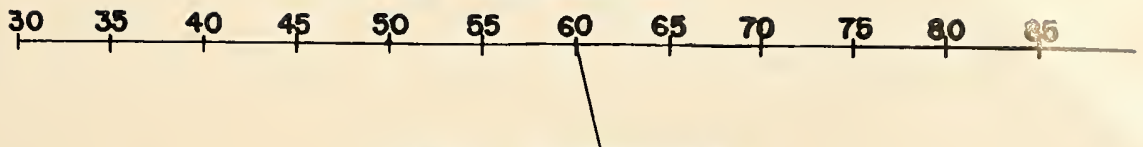

OUTSIDE TEMPERATURE

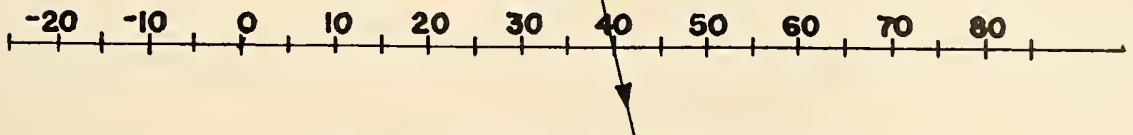

TEMPERATURE DIFFERENCE ( $\triangle t)$

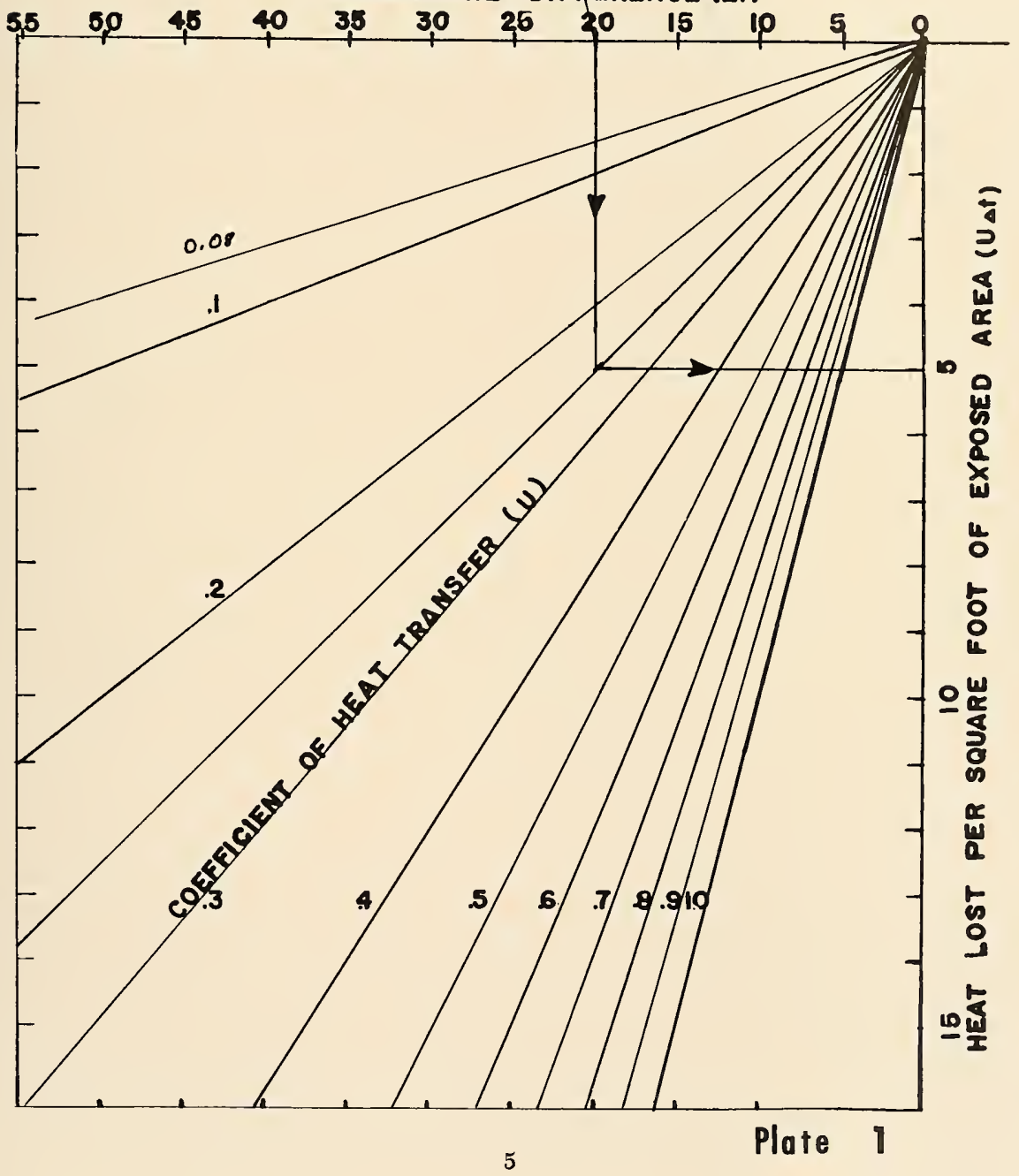




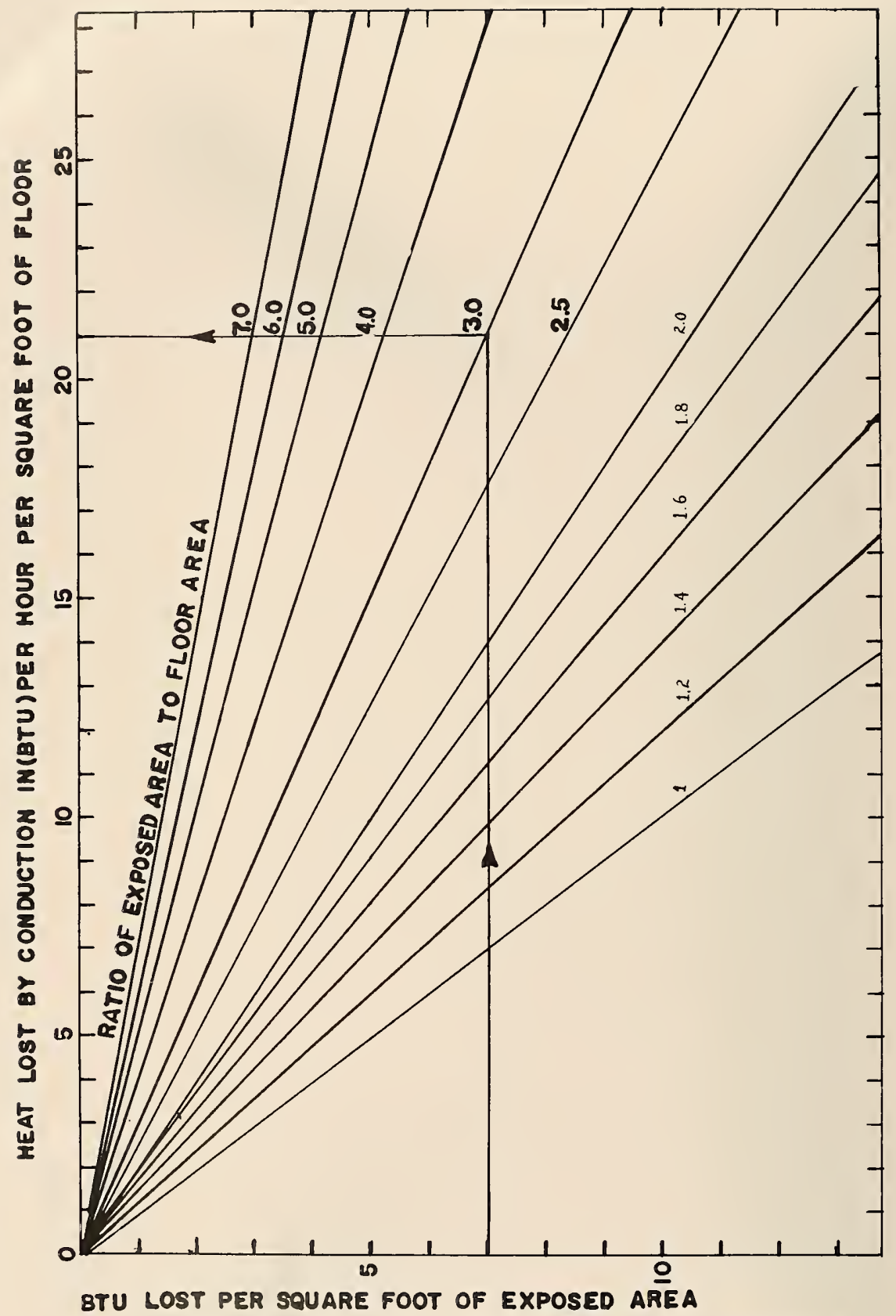

Plate 2 


$$
\begin{aligned}
& \mathrm{l}=\text { house length } \\
& \mathrm{b}=\text { house width } \\
& \mathrm{h}=\text { house height } \\
& \mathrm{r}=\mathrm{l} / \mathrm{b}, \text { a ratio }
\end{aligned}
$$

Plate 4 was developed for a square house. Plate 3 is a multiplication nomograph which adjusts the ratio of the exposed area to the floor area for houses which are not square. It was assumed in designing this nomograph that the ceiling of the house was in one plane. It can be a flat ceiling with a roof of any shape, or a sloped roof in one plane, either ceiled or unceiled.

For any roof shape other than a flat roof, the $U$ value of the roof must be calculated in terms of the ceiling area. If the ceiling is not flat, but is in a single plane, then the average height of the ceiling can be used as the room height.

In developing this equation, it was also assumed that cold air would not be permitted to blow under the floor of the poultry house, that no fill would be piled against the walls, nor would there be rooms on the side of, above, or beneath the house. If actual conditions are different than as assumed, the following equations may be used to determine the ratio of exposed area to floor area.

When the ceiling is not flat, compute the ratio with this equation:

$$
\begin{aligned}
E & =\left(A_{w}+A_{c}\right) / A_{e} \\
& =\text { ratio of exposed area to floor area }
\end{aligned}
$$

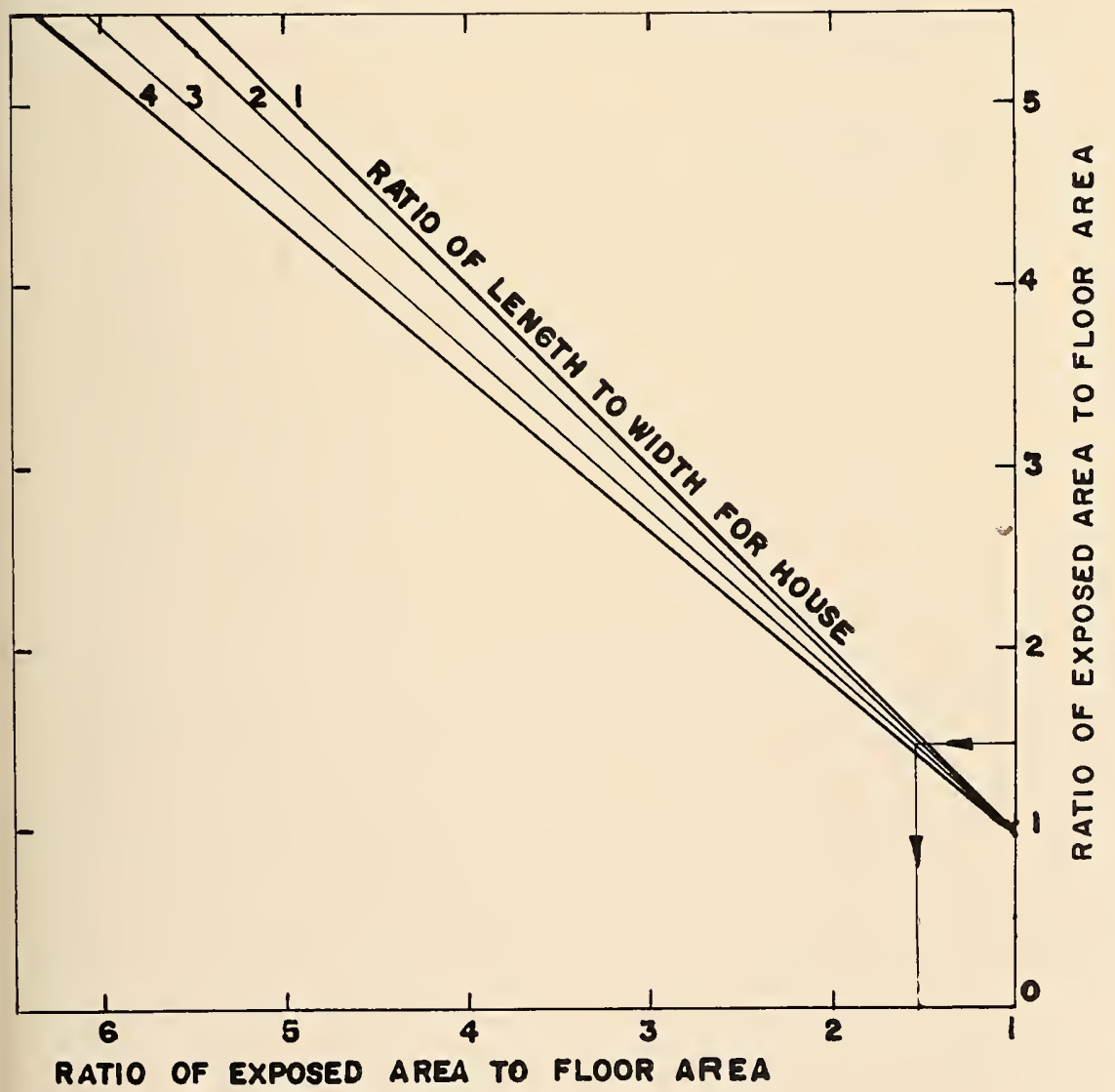




$$
\begin{aligned}
& A_{w}=\text { area of the wall } \\
& A_{t}=\text { area of the ceiling } \\
& A_{t}=\text { area of the floor }
\end{aligned}
$$

If the building is supported above the ground, the equation used is:

$$
\mathrm{E}=\left(\mathrm{A}_{*}+\mathrm{A}_{\mathrm{c}}-\mathrm{A}_{\mathrm{z}}\right) / \mathrm{A}_{\mathrm{s}}
$$

If part of the wall of the building is banked up with soil, the equation is used in this form:

$$
\mathrm{E}=\left(\mathrm{A}_{w}+\mathrm{A}_{\mathrm{c}}-\mathrm{A}_{\mathrm{ug}}\right) / \mathrm{A}_{\mathrm{e}}
$$

$A_{\text {чв }}=$ area of portion of wall covered with soil

If there is a room adjoining the building being analyzed, the effective wall and ceiling area will be reduced. The reduction will be equal to the area of the wall covered by the adjacent room, provided the temperature of that room is the same as that of the building in question. If there is a difference in temperature between the two, the ratio will be reduced or increased accordingly. The following equation indicates the ratio:

$$
\begin{aligned}
\mathrm{E}=\left[\left(\mathrm{A}_{*}+\mathrm{A}_{\mathrm{c}}-\mathrm{A}_{* \mathrm{w}}\right)\left(\mathrm{T}_{0}-\mathrm{T}_{0}\right) /\left(\mathrm{T}_{1}-\mathrm{T}_{0}\right)\right] / \mathrm{A}_{t} & (\mathrm{VI}) \\
\mathrm{A}_{\mathrm{aw}}= & \text { the area of the wall covered by the } \\
& \text { adjacent room } \\
\mathrm{T}_{0}= & \text { outside temperature } \\
\mathrm{T}_{0}= & \text { temperature of adjacent room } \\
\mathrm{T}_{1} & =\text { temperature of the room in question }
\end{aligned}
$$

If there is a room above the room being analyzed, it can be handled by this equation in the same manner. The equation is:

$$
\begin{aligned}
E=\left[\left(A_{*}+A_{e}-A_{* e}\right)\left(T_{*}-T_{0}\right) /\left(T_{1}-T_{0}\right)\right] / A_{\ell} & (V \\
A_{a c}= & \underset{r e a}{\text { areom }}
\end{aligned}
$$

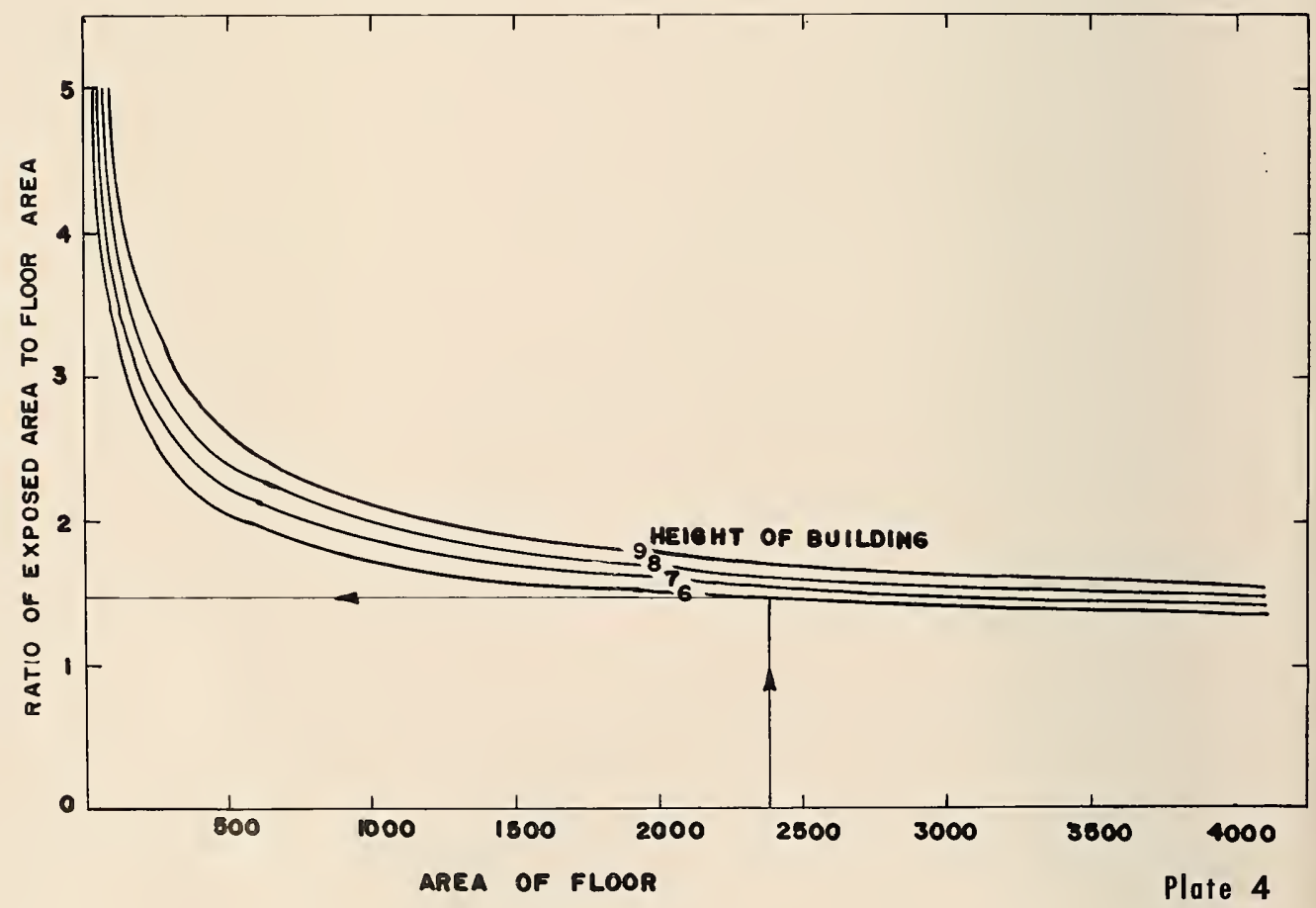


HEAT LOST BY VENTILATION IN(BTU) PER HOUR PER SQUARE FOOT OF FLOOR
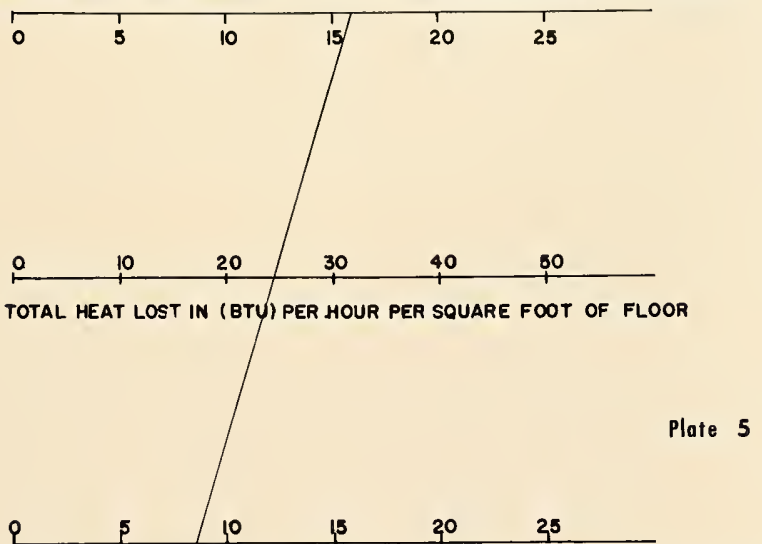

HEAT LOST BY CONOUCTION IN (BTU) PER HOUR PER SQUARE FOOT OF FLOOR

A room beneath the floor can increase or decrease the ratio of exposed area to floor area in the same

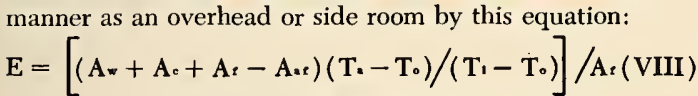
$A_{\mathrm{a} \varepsilon}=$ area of the floor with the room under it

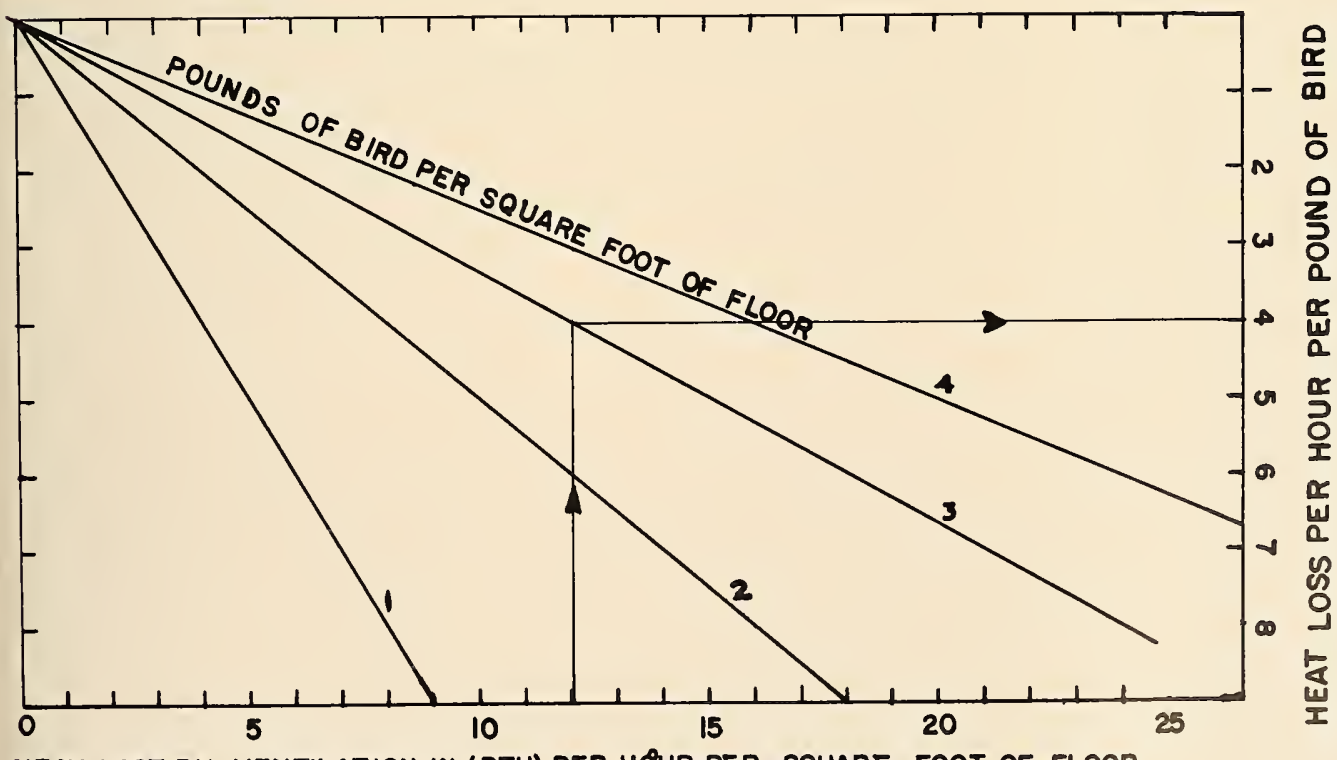

HEAT LOST BY VENTILATION IN (BTU) PER HOUR PER SQUARE FOOT OF FLOOR room temperature, use this equation:

$E=\left[\left(A_{w}+A_{c}+\dot{A}_{t}-A_{t r}\right)\left(T_{* r}-T_{0}\right) /\left(T_{1}-T_{0}\right)\right] / A_{2}$ 
If the house meets the specifications listed, Plates 3 and 4 can be used to determine the ratio of exposed area to floor area.

\section{PLATE 5}

Plate 5 is an addition nomograph used to determine the total heat loss per hour from the house (conduction heat loss per hour plus ventilation heat loss per hour).

\section{PLATE 6}

Plate 6 is a multiplication nomograph which converts heat loss per pound of bird to heat loss per square foot of floor per hour. The heat loss per pound of bird per hour is multiplied by the pounds of bird per square foot of floor.

\section{PLATE 7}

Plate 7 is a multiplication nomograph which is used to determine the heat loss by ventilation per hour per pound of bird. The pounds of air circulated per hour per pound of bird is multiplied by the heat required to change one pound of air from outside to inside conditions.

$$
\begin{aligned}
& Q=P S \\
& Q=\text { heat required per pound of bird (Btu) } \\
& P=\text { pound of air per pound of bird per hour } \\
& S=\text { heat required per pound of air (Btu) }
\end{aligned}
$$

\section{PLATE 8}

Plate 8 is a subtraction nomograph which includes the enthalpy inside, $\mathrm{H}_{\mathrm{s}}$, enthalpy outside, $\mathrm{H}_{0}$, and the enthalpy difference, $\Delta H$, scales. The nomograph is used to determine the heat required to change one pound of outside air to inside conditions $\left(\mathrm{H}_{1}-\mathrm{H}_{0}\right)$. Plates $8 \mathrm{~A}$ and $8 \mathrm{~B}$ were developed from a psychrometric chart so that $H_{1}$ and $H_{0}$ can be determined readily.

\section{PLATE 9}

Plate 9, a division nomograph, is used to determine the pounds of air required per hour per bird to remove a given quantity of moisture. In this section; the grains of moisture produced per pound of bird per hour is divided by the grains of moisture removed per pound of air.

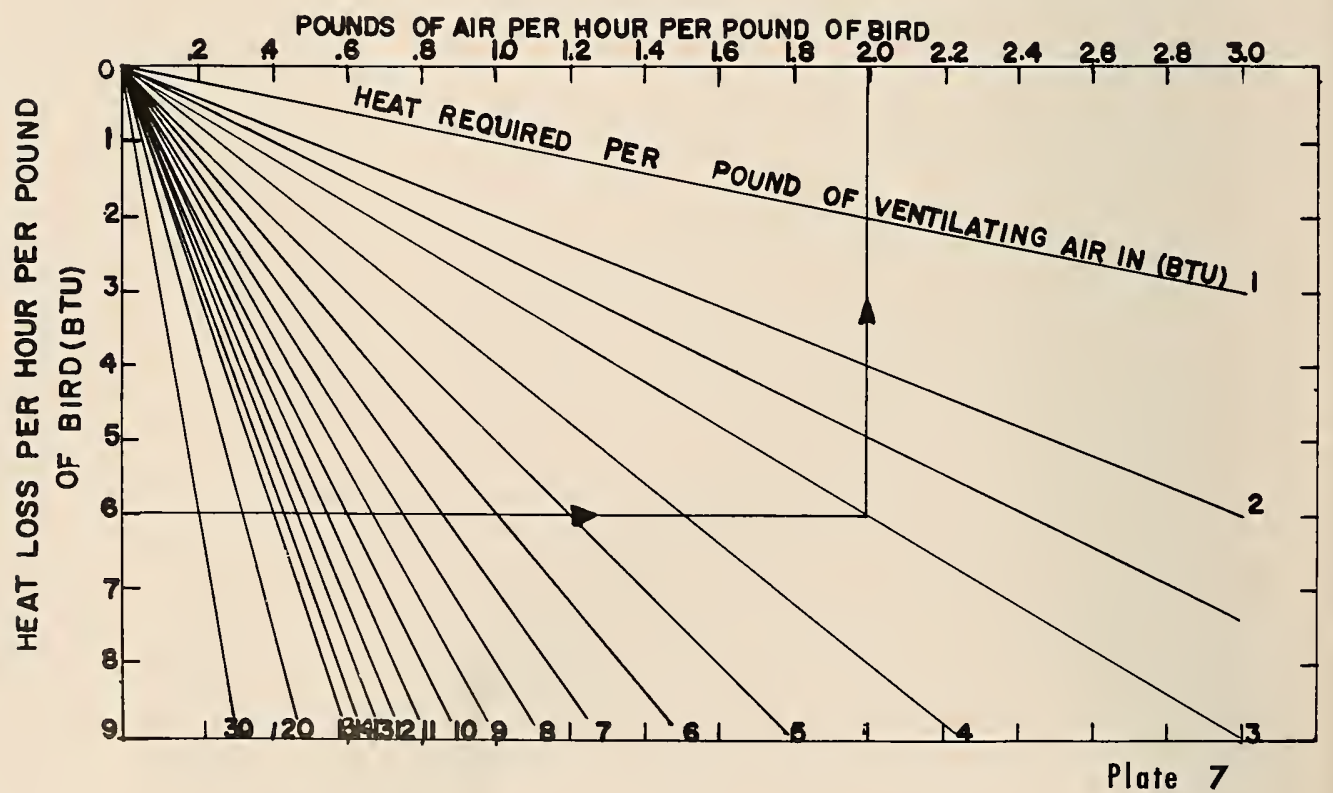




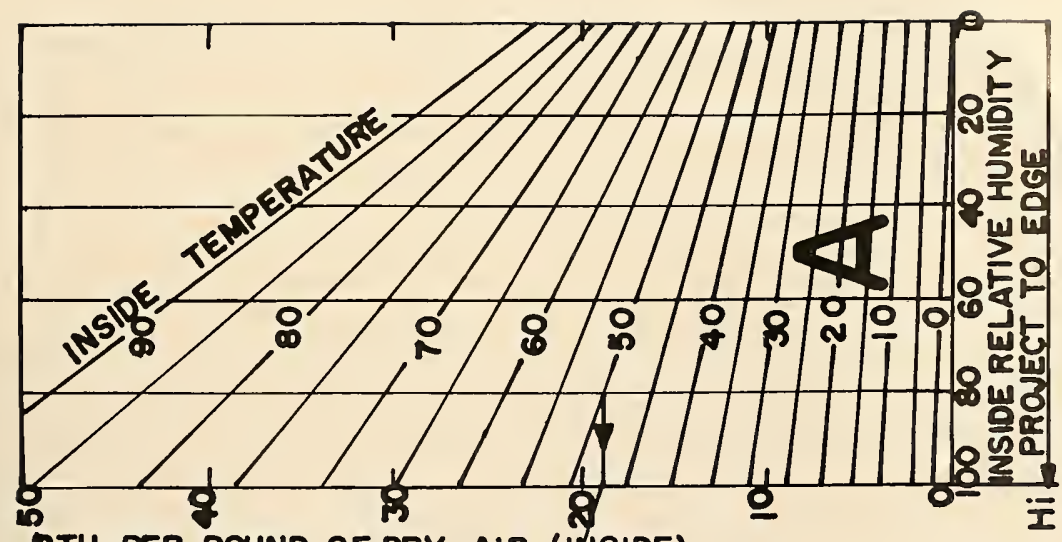

BTU PER POUND OF DRY AIR (INSIDE)

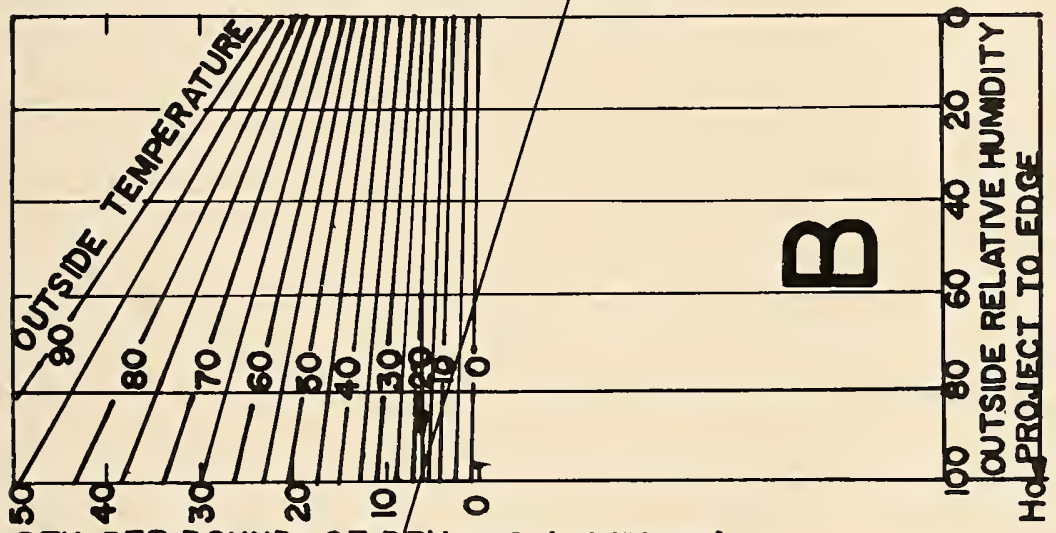

BTU PER POUND OF QRY AIR (OUTSIDE)

Plate 8

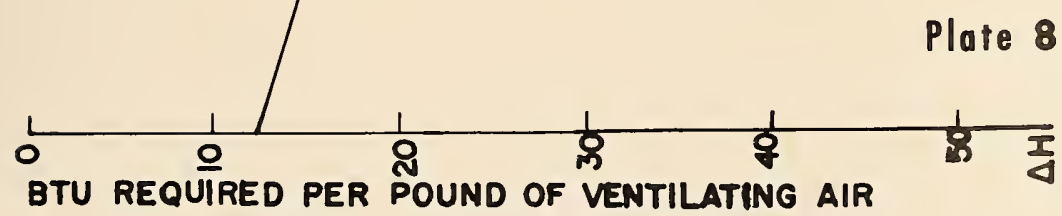




$$
\mathrm{P}=\mathrm{W} / \triangle \mathrm{W}
$$

$\mathrm{P}=$ pounds of air per hour per pound of bird

$\mathrm{W}=$ moisture (grains) to be removed per hour per pound of bird

$\Delta W^{\top}=$ moisture (grains) removed per pound of air

\section{PLATE 10}

Plate 10 is a subtraction nomograph which includes the total moisture inside, $W_{i}$, total moisture outside, $W_{\circ}$, and the difference, $\Delta W$, scales. It is used to determine the difference in moisture content $\left(W_{1}-W_{0}\right)$. Plates $10 \mathrm{~A}$ and $10 \mathrm{~B}$ were developed from a psychrometric chart so that the moisture content of inside and outside air could be determined readily.

\section{USING THE NOMOGRAPH}

\section{Example Problems for Individual Plates}

\section{PROBLEM ONE}

Determine the heat loss per square foot of exposed area when the inside temperature is $60^{\circ} \mathrm{F}$., the outside temperature is $40^{\circ} \mathrm{F}$., and the average coefficient of heat transfer is $0.25 \mathrm{Btu} / \mathrm{hr} / \mathrm{ft}^{2} /{ }^{\circ} \mathrm{F}$.

\section{Solution}

Using Plate 1 , locate the inside temperature, $60^{\circ}$ $\mathrm{F}$., on the inside scale and the outside temperature, $40^{\circ} \mathrm{F}$., on the outside scale. Draw a straight line through these points and extend the line until it intersects the $\Delta t$ scale. Extend the line, perpendicular to $\Delta t$ scale, until it intersects the curve that represents the average coefficient of heat transfer, $0.25 \mathrm{Btu} / \mathrm{hr} /$ $\mathrm{ft}^{2} /{ }^{\circ} \mathrm{F}$. At this point pivot and move to the righthand scale, and read the heat lost per square foot of exposed area: $5 \mathrm{Btu} / \mathrm{hr}$.

The coefficient of heat transfer may be determined from Plate 1.

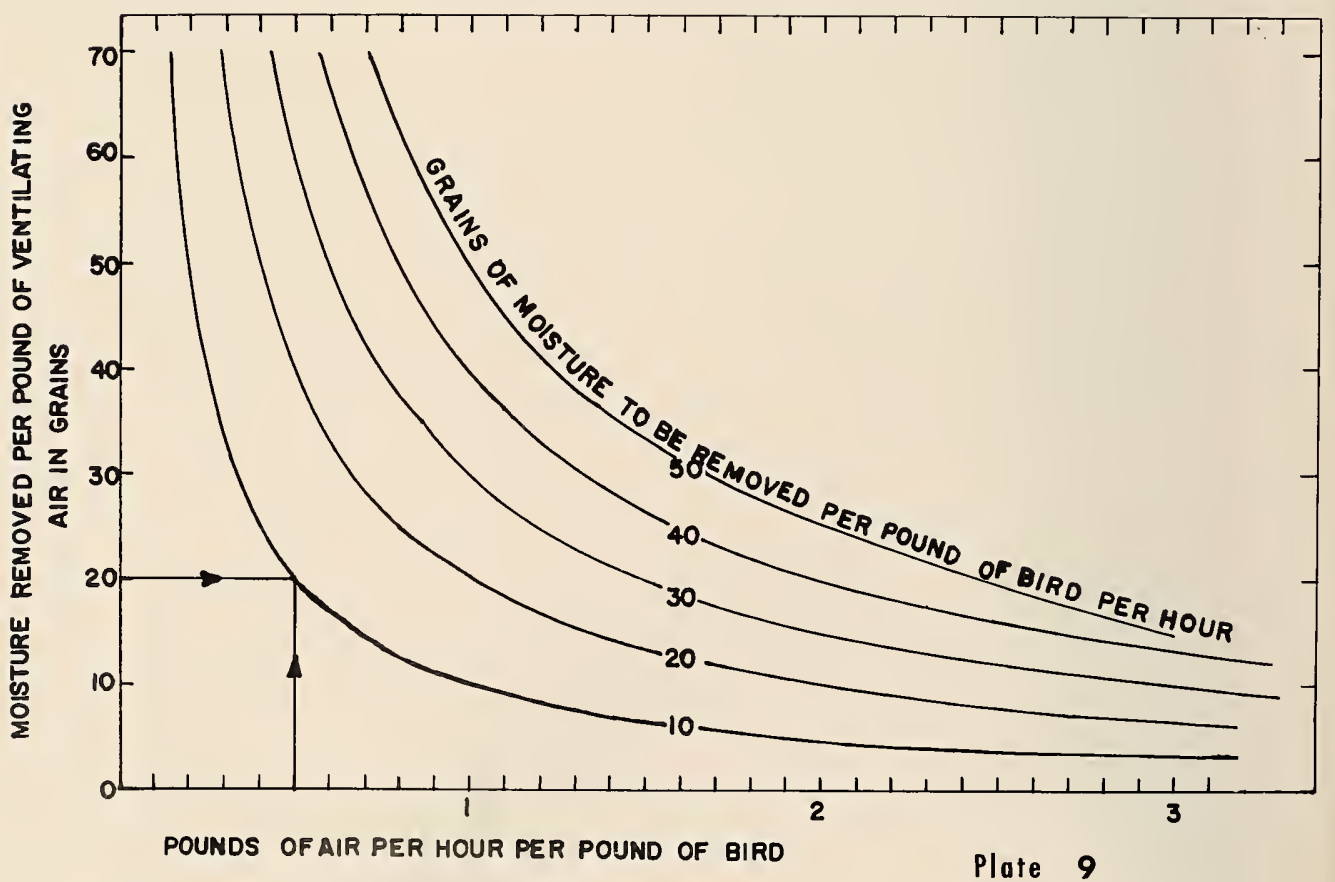


MOISTURE REMOVED PER POUND OF VENTILATING AIR IN GRAINS

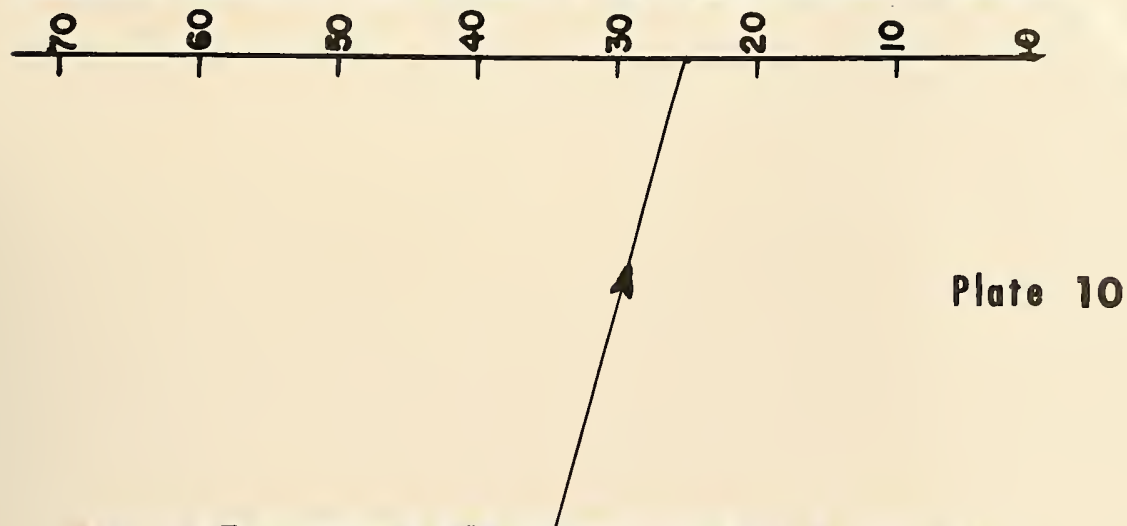

GRAINS OF MOISTURE PER POUND OF DRY AIR (OUTSIDE)
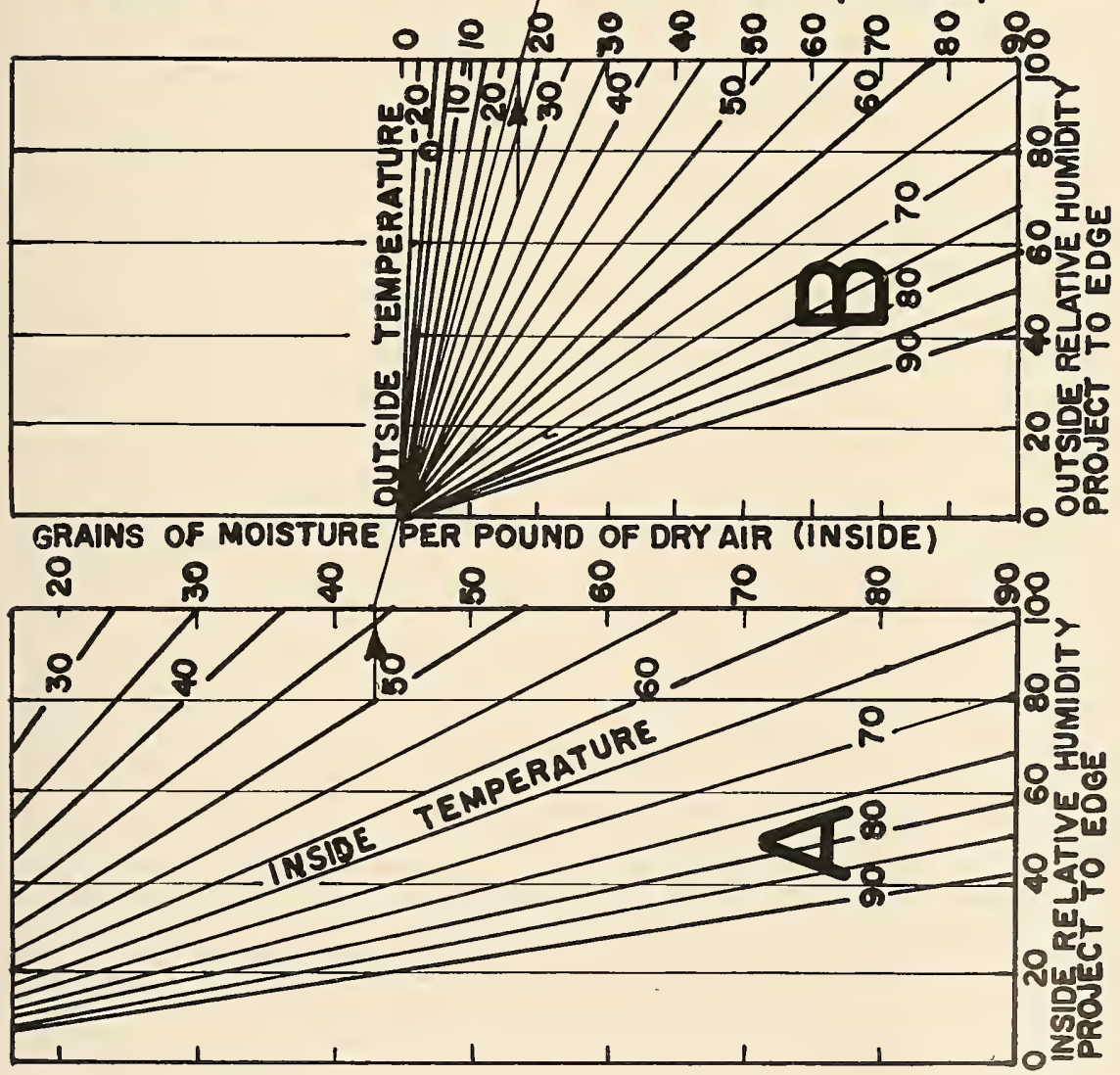


\section{PROBLEM TWO}

Convert heat lost per square foot of exposed area to heat loss per square foot of floor when heat lost per square foot of exposed area is $7 \mathrm{Btu} / \mathrm{hr}$ and the ratio of exposed area to floor area is 3 .

\section{Solution}

Using Plate 2, locate heat lost per square foot of exposed area, $7 \mathrm{Btu} / \mathrm{hr}$, on the vertical scale, and project a line until it intersects the curve that describes the ratios of exposed area to floor area, 3 . Pivot and move to the upper scale, and read the heat loss per square foot of floor: $21 \mathrm{Btu} / \mathrm{hr}$.

Heat loss per square foot of floor area to heat loss per square foot of exposed area may be determined from Plate 2.

\section{PROBLEM THREE}

Determine the ratio of exposed area to floor area when floor area is 2,400 square feet, house height is 6 feet, and the ratio of length to width is 2 .

\section{Solution}

Using Plate 4, locate the floor area, 2,400 square feet, on the base scale and project this point until it intersects the curve representing building height, 6 feet. Pivot and move out of Plate 4 into Plate 3 to the curve that describes the ratio of building length to width, 2. Pivot and move to the base scale of Plate 3 and read the ratio of exposed area to floor area: 1.5 .

\section{PROBLEM FOUR}

Determine the total heat needed for ventilation and conduction losses when ventilation losses are 16 $\mathrm{Btu} / \mathrm{hr}$ per hour per square foot of floor and conduction losses are $8 \mathrm{Btu}$ per hour per square foot of floor.

\section{Solution}

Using Plate 5, locate the ventilation loss, 16 $\mathrm{Btu} / \mathrm{hr} / \mathrm{ft}^{2}$, on the upper scale and the conduction loss, $8 \mathrm{Btu} / \mathrm{hr} / \mathrm{ft}^{2}$, on the base scale. Connect these points with a straight line, read the sum of the two losses at the intersection on the center scale: 24 $\mathrm{Btu} / \mathrm{hr} / \mathrm{ft}^{2}$.

The permissible heat loss to ventilating air and the heat available for conduction loss may be established from Plate 5.

\section{PROBLEM FIVE}

Convert the heat loss per square foot of floor to heat loss per pound of bird when bird density is 3 pounds per square foot and ventilation heat loss is $12 \mathrm{Btu} / \mathrm{hr} / \mathrm{ft}^{2}$.

\section{Solution}

Using Plate 6, locate heat loss per square foot of floor, $12 \mathrm{Btu} / \mathrm{hr}$, on the base scale and project this to the curve that represents bird density, 3 pounds per square foot. Pivot and move to the right-hand scale and read the heat loss per pound of bird: $4 \mathrm{Btu} / \mathrm{hr}$.

Heat loss per pound of bird to heat loss per square foot of floor may be determined with Plate 6 .

\section{PROBLEM SIX}

Determine the allowable air flow when the heat available is $6 \mathrm{Btu} / \mathrm{hr}$ per pound of bird and the heat required is 3 Btu per pound of air.

\section{Solution}

Using Plate 7, locate on the vertical scale the heat available, $6 \mathrm{Btu} / \mathrm{hr}$ per pound of bird. Project a line from this point until it intersects the appropriate curve for heat required to convert outside air to inside conditions, 3 Btu per pound of air. Pivot and move to the upper scale and read the allowable air flow: $2 \mathrm{lb} / \mathrm{hr} /$ pound of bird. This is the equivalent to $2 / 60 \times 13.00$ (specific volumes of air) or $0.432 \mathrm{cfm}$ per pound of bird.

The heat loss for a given rate of ventilation may also be determined from Plate 7 .

\section{PROBLEM SEVEN}

Determine the heat required to convert one pound of outside air to inside conditions when inside temperature is $50^{\circ} \mathrm{F}$, inside relative humidity is 80 per cent, outside temperature is $20^{\circ} \mathrm{F}$., and outside relative humidity is 60 per cent.

\section{Solution}

Using Plate $8 \mathrm{~A}$, locate the point where the inside temperature curve for $50^{\circ} \mathrm{F}$. intersects the inside relative humidity curve for 80 per cent. Project this point to the $\mathrm{H}_{1}$ scale. On Plate $8 \mathrm{~B}$, connect the point where the outside temperature curve for $20^{\circ} \mathrm{F}$. intersects the outside relative humidity curve for 60 per cent with the $\mathrm{H}_{0}$ scale. A line connecting the points on the $H_{\mathrm{i}}$ and $H_{0}$ scales and extended through the $\Delta H$ scale will indicate the heat required to change one pound of outside air to inside conditions: $13 \mathrm{Btu}$. 


\section{PROBLEM EIGHT}

Determine moisture removed when the air flow is 0.5 pounds per hour per pound of bird and the moisture removed is 20 grains per pound of air.

\section{Solution}

Using Plate 9, locate on its base line the air flow, $0.5 \mathrm{lb} / \mathrm{hr} /$ pound of bird. Construct a vertical reference line at this point. On the vertical scale, locate the point for moisture removed per pound of dry air, 20 grains. Construct a horizontal reference line at this point. The two reference lines will intersect at the point representing the moisture removed per hour per pound of bird: 10 grains.

The air required to remove a given quantity of moisture under a given set of conditions may be determined with Plate 9.

\section{PROBLEM NINE}

Determine the grains of moisture removed per pound of dry air when the inside temperature is $50^{\circ} \mathrm{F}$., the inside relative humidity is 80 per cent, the outside temperature is $30^{\circ} \mathrm{F}$, and the outside relative humidity is 70 per cent.

\section{Solution}

Using Plate $10 \mathrm{~A}$, locate the point where the inside temperature curve for $50^{\circ} \mathrm{F}$. intersects the inside relative humidity curve for 80 per cent. Project this point to the $W_{1}$ scale. In Plate $10 \mathrm{~B}$, locate the intersection of the outside temperature curve for $30^{\circ} \mathrm{F}$. and the curve for 70 per cent outside relative humidity. Project this point to the $W_{\text {。 }}$ scale. A straight line connecting the points of the $W_{1}$ and $W_{0}$ scales and extended until it intersects the $\Delta W$ scale will indicate the moisture removed per pound of dry air: 25 grains.

\section{Use of the Nomograph for Design}

\section{DESIGN PROCEDURE ONE}

Determine the required coefficient of heat transfer for a new house.

1. Determine heat required to change air from outside to inside conditions, Plate 8 .

2. Determine the ratio of exposed area to floor area, Plates 3 and 4.
3. Determine moisture removed per pound of ventilating air, Plate 10.

4. Determine pounds of air per hour per pound of bird, Plate 9 .

5. Determine heat loss by ventilation per hour per pound of bird, Plate 7 .

6. Convert ventilation heat loss per hour per pound of bird to ventilation heat loss per hour per square foot of floor, Plate 6.

7. Determine heat available for conduction losses per hour per square foot of floor, Plate 5.

8. Convert allowable conduction heat loss per hour per square foot of floor to allowable-conduction heat loss per hour per square foot of exposed area, Plate 2.

9. Determine the necessary coefficient of heat transfer, Plate 1.

\section{DESIGN PROCEDURE TWO}

Determine the allowable air flow for a given house based on available heat.

1. Determine heat required to change outside air to inside conditions, Plate 8 .

2. Determine ratio of exposed area to floor area, Plates 3 and 4.

3. Determine heat loss by conduction per hour per square foot of exposed area, Plate 1.

4. Convert conduction heat loss per hour per square foot of exposed area to conduction heat loss per square foot of floor, Plate 2.

5. Determine allowable ventilation heat loss per hour per square foot of floor, Plate 5 .

6. Convert the ventilation heat loss per hour per square foot of floor to heat loss per hour per pound of bird, Plate 6.

7. Determine pounds of air allowable per hour per pound of bird, Plate 7 .

8. Multiply pounds of air per hour per pound of bird by the specific volume of air to get the $\mathrm{cfh}$ per pound of bird.

\section{DESIGN PROCEDURE THREE}

Determine the air flow needed to remove a given quantity of moisture from the house.

1. Determine the quantity of moisture removed by each pound of ventilating air, Plate 10 . 
2. Determine pounds of air required per hour per pound of bird, Plate 9 .

3. Multiply the pounds of air per hour per pound of bird by the specific volume of air to get $\mathrm{ch}$ per pound of bird.

\section{Conclusions}

The accuracy of this procedure for determining ventilation and insulation requirements for poultry is dependent upon the validity of the basic assumptions one makes when using it. Since the nomograph is a graphical representation of proven and accepted psychrometric and calorimetric equations, errors become possible only when inaccurate assumptions are made. Knowing which data to use and which assump- tions to make are the greatest problems encountered in using the nomograph.

The most advantageous feature of this nomograph is its flexibility, gained by the use of basic data instead of fixed assumptions. The heat and moisture produced by a bird, for example, are variable. Workers who do not agree with the quantities used here may substitute the values they desire. Any combination of outside and inside environmental conditions can be used.

Equations for determining the ratio of exposed area to floor area for rooms where walls are not exposed, floors are not on the ground, and roofs not flat are provided.

This nomograph is not limited to use with problems in poultry housing. It can be adjusted to almost any heating, ventilating, or insulating problem. The scales on the individual plates can be extended so that larger quantities of heat and moisture can be handled.

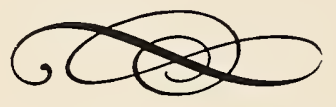

\section{SYMBOLS AND NOMENCLATURE USED IN THIS BULLETIN}
A ac - area of ceiling covered by the overhead room
Aat - area of floor with the room under it
Aaw - area of wall covered by adjacent room
A. - area of ceiling
A. - area of floor
$A_{u k} \quad$ - area of wall which is underground
Aw - area of wall
b - house width
E - ratio of exposed area to floor area
h - house height
1 - house length
$P \quad$ - pound of air per pound of bird per hour
Q - heat required per pound of bird (Btuh)



